The Catholic University of America, Columbus School of Law

CUA Law Scholarship Repository

1986

\title{
The APA: An Administrative Conference Perspective
}

Marshall J. Breger

The Catholic University of America, Columbus School of Law

Follow this and additional works at: https://scholarship.law.edu/scholar

Part of the Administrative Law Commons

\section{Recommended Citation}

Marshall J. Breger, The APA: An Administrative Conference Perspective, 72 VA. L. REV. 337 (1986).

This Article is brought to you for free and open access by the Faculty Scholarship at CUA Law Scholarship Repository. It has been accepted for inclusion in Scholarly Articles and Other Contributions by an authorized administrator of CUA Law Scholarship Repository. For more information, please contact edinger@law.edu. 


\section{THE APA: AN ADMINISTRATIVE CONFERENCE PERSPECTIVE}

\section{Marshall J. Breger*}

TUNE 11, 1986 marks the fortieth anniversary of the passage of the Administrative Procedure Act (APA). ${ }^{1}$ After four decades of extensive experience with the APA, this symposium issue of the Virginia Law Review offers an opportunity to step back and examine the Act in a broader legal and political perspective. As Chairman of the Administrative Conference of the United States, I welcome this symposium and the opportunity to make these comments.

Congress established the Administrative Conference as a permanent body to "study the efficiency, adequacy, and fairness of the administrative procedure used by administrative agencies in carrying out administrative programs, and make recommendations to administrative agencies, collectively or individually, and to the President, Congress, or the Judicial Conference of the United States, in connection therewith."' The Conference is, in effect, the administering agency of the APA and the only government agency with a primary and continuing interest in administrative procedure throughout the federal government. ${ }^{3}$ Pursuant to its legislative mandate, the Conference has, over the past eighteen years, continually reviewed agency experience under the APA and formulated proposals for improvement of the administrative process. The Conference has adopted over one hundred recommendations since

* Chairman, Administrative Conference of the United States; Associate Professor of Law, New York Law School (on leave); B.A., M.A. University of Pennsylvania, 1967; B. Phil. (Oxon.), Oxford University, 1970; J.D. University of Pennsylvania, 1973. I would like to thank Richard Berg for his incisive assistance.

The views expressed in this article are those of the author and not necessarily those of the Administrative Conference.

1 Administrative Procedure Act, ch. 324, 60 Stat. 237 (1946) (current version codified at 5 U.S.C. $\$ \$ 551-559,701-706,1305,3105,3344$ (1982)).

25 U.S.C. $\$ 574(1)$ (1982).

${ }^{3}$ See McGowan, The Administrative Conference: Guardian and Guide of the Regulatory Process, 53 Geo. Wash. L. Rev. 67 (1985). See also Boley, Administrative Conference of the United States: Bibliograplyy 1968-1983, 36 Ad. Law Rev. 307 (1984). 
1968, each backed by research reports; these recommendations may well comprise the best collection of continuing commentary on the Act and related topics. ${ }^{4}$ Because of this ongoing review, the Administrative Conference remains the body most responsible for providing the conceptual bridge between the Act's energetic past and its uncertain future.

An Administrative Conference perspective on the APA begins with the history of failed attempts to reform the APA. This does not mean that the APA's basic structure has not proved sound. For it has. Its weaknesses, if any, have been glossed over by judicial interpretation. Indeed, some of the reform bills may have attempted to do too much. Nevertheless, with the growth in the number of agencies, and the more adversarial atmosphere that attends today's regulated state, it is important that the APA remain a relevant document that permits apphication of innovation and fair and efficient procedure while serving as a unifying force in government operations. This article traces five potential areas of revision to the APA that Congress should consider in order to preserve the guiding role of the APA in administrative procedure. This focus on statutory change highlights and accomodates the significant changes that have occurred over the past four decades.

\section{BACKGROUND}

Congress enacted the Administrative Procedure Act in 1946, ${ }^{5}$ largely in response to the tremendous and unprecedented expansion of the administrative state during the New Deal period and the concomitant backlash to this expansion in the legal and business communities." As Justice Jackson observed, the Act "repre-

4 The recommendations of the Conference can be found at I C.F.R. $\S 305$ et seq. (1985). The Conference publishes a compilation of its recommendations and reports which is cited as "A.C.U.S.," and an annual report which is cited as "Report, Admin. Conf. of the U.S." The Conference has also published guidebooks on tbese matters: R. Berg \& S. Klitzman, An Interpretive Guide to the Government in the Sunshine Act (1978); M. Ruhlen, Manual for Administrative Law Judges (Revised 1982); Admin. Conf. of the U.S., Federal Administrative Procedure Sourcebook (Office of the Chairman 1985); Admin. Conf. of the U.S., Guide to Federal Agency Rulemaking (1983).

S Supra note 1.

- See generally, Administrative Procedure Act-Legislative History 1944-46, S. Doc. No. 248, 79th Cong., 2d Sess. (1946); House of Representatives Committee on the Judiciary, Report on S. 7, H.R. Rep. No. 1980, 79th Cong., 2d Sess. (1946); Administrative Procedure in Government Agencies, S. Doc. No. 8, 77th Cong., 1st Sess. (1941)(Final Report of the 
sents a long period of study and strife; it settles long-continued and hard-fought contentions, and enacts a formula upon which opposing social and pohtical forces have come to rest." The Act achieved this consensus by relying on a vision of an administrative process applying balanced and sober expertise to the solution of social problems. This vision regarded process as rational and neutral, favoring neither the interests of the regulators nor the regulated. ${ }^{8}$

Developments of the past twenty years have shaken, perhaps shattered, this neutral vision of the administrative state. ${ }^{9}$ The expansion of regulation during the late 1960's rejected the vision of the agency as a neutral technocrat regulating in "the public interest" and instead embraced the agency as a champion of putatively unprotected interest groups, such as poor people, racial minorities, consumers, and victims of pollution. Regulatory reformers beheved that these groups had received inadequate protection from bureaucratic agencies prescribing cures for social ills. This vision of administrative law ineasured the quality of procedure by the degree to which it aided the unprotected. The Reagan regulatory counterrevolution holds a very different view of the administrative agency. This group of regulatory reformers views agencies as, at best, well intentioned but officious intermeddlers and, at worst, a source of illegitimate government coercion and a barrier to economic efficiency. ${ }^{10}$ These reformers beheve that a focus on procedure for its own sake is often an obstacle to seizing opportunities to withdraw the state from areas that are best left to market forces. Given these vast shifts in the prevailing vision of the administrative process, the paucity of amendments to the APA is remarkable.

Indeed, since the APA's inception, Congress has crafted only three significant amendments to the Act. ${ }^{11}$ The most important of

Attorney General's Committee on Administrative Procedure).

7 Wong Yang Sung v. McGrath, 339 U.S. 33, 40 (1950).

- See, e.g., J. Landes, The Administrative Process 23-26 (1938); Stewart, The Reformation of Administrative Law, 88 Harv. L. Rev. 1667, 1677-78 (1975).

- Stewart, supra note 8, at 1723-60. See also Frug, Why Neutrality?, 92 Yale L.J. 1591 (1983).

10 Sargentich, The Reform of the American Administrative Process: The Contemporary Debate, 1984 Wis. L. Rev. 385, 390-91.

"Congress has enacted some other, nonsubstantive changes. Numerous stylistic changes accompanied the enactment of title 5 of the U.S. Code in 1966. See Pub. L. No. 89-554, 80 Stat. 378 (1966). The codification was not intended to effect substantive changes. H.R. Rep. 
these amendments was the Freedom of Information Act (FOIA), adopted in 1967 and amended in 1974. ${ }^{12}$ This legislation reflected an important shift in popular attitudes toward government secrecy and the public's right to know. Although part of the APA, the Freedom of Information Act has become a separate subject area with little functional relationship to the rest of administrative procedure. In 1976, Congress amended the APA to abolish the doctrine of sovereign immunity and certain other technical barriers to nonstatutory review of agency action. ${ }^{13}$ Also in 1976, Congress passed the Government in the Sunshine Act, which strengthened a prohibition against ex parte communications in formal agency proceedings. This amendment, actively sought by bar groups, generally conformed to existing agency practice. ${ }^{14}$

The lack of significant amendments to the APA obscures, however, the number of studies undertaken and administrative reforms proposed. Over the years, a number of prolonged and serious reform campaigns have been launched for substantial revision.

In the late 1950's, the American Bar Association lobbied Congress for a comprehensive Code of Federal Administrative Procedure to replace the APA. A bill to that effect was introduced in $1959,{ }^{15}$ and efforts to enact the code or to amend the APA along similar lines continued through the mid-1960's. ${ }^{16}$ These bills proposed to establish formal administrative proceedings that would

No. 901, 89th Cong., 1st Sess. 1 (1965). In 1978, Congress retitled hearing examiners as administrative law judges. Pub. L. No. 95-251, 92 Stat. 183 (1978).

12 Pub. L. No. 89-487, 80 Stat. 250 (1966). Congress enacted the Freedom of Information Act in 1966 as an amendment to section 3 of the APA, to take effect in 1967. In the interval Congress passed the codification of title 5 of the U.S. Code, supra note 12. In 1974, Congress substantially strengthened the FOIA. Pub. L. 93-502, 88 Stat. 1561 (1974). There have also been a number of less significant amendments since 1974. 5 U.S.C. $\$ 552$ (1982).

13 Pub. L. No. 94-574, 90 Stat. 2721 (1976) implemented three early recommendations of the Administrative Conference. Recommendations 68-7, 69-1, and 70-1, 1 C.F.R. $\S \S 305.68-7$, 69-1, 70-1 (1985).

14 See S. Rep. No. 354, 94th Cong., 1st Sess. 8-9 (1975), (Comm. on Government Operations); H. Rep. No. 880, Pt. I and II, 94th. Cong., 1st Sess. (1975), (Committee on Government Operations). Government in the Sunshine Act, Sourcebook: Legislative History, Text and Other Documents, 342-44 (1976) (Joint Committee Print of the Government Operations Committees of the Senate and House). See also Berg and Klitzman, supra note 4, at 111.

${ }^{18} \mathrm{~S}$. Res. 61, 86th Cong., 1st Sess. (1959).

18 See ABA Proposals for the Amendments to the Administrative Procedure Act, 24 Ad. L. Rev. 371, 383-411, 565-670 (1972). The entire issue is devoted to a discussion of the legislative efforts in the 1960's and the 12 recommendations adopted by the ABA House of Delegates in 1970. 
conform closely to the judicial model of decisionmaking by increasing the separation of the enforcement and adjudication functions and by augmenting both the authority and status of hearing examiners (now administrative law judges) and the weight given to their decisions. These codes also included procedures for informal adjudication and rulemaking as well as procedures to expand the scope of judicial review. The bills had strong support, especially in the Senate Judiciary Committee, but agency opposition eventually blocked their passage. ${ }^{17}$

In the 1970's, the reform effort was renewed, albeit on a more modest scale. In 1970 the ABA House of Delegates adopted twelve recommendations for improvements in the APA and referred them to a drafting committee of the Administrative Law Section for preparation of statutory language. ${ }^{18}$ Mindful of the failures of the 1960's, the Section decided to work with the Administrative Conference on these amendments and to focus its effort on those amendments that the Conference would approve. The Conference recommended only four of the twelve:"19 (1) redefining "rule" as a generally applicable agency action and "order" as an agency action with a particular application, ${ }^{20}(2)$ narrowing the exemptions from the requirement for notice and comment rulemaking, ${ }^{21}$ (3) increasing agency authority to delegate decisionmaking, ${ }^{22}$ and (4) increasing the availability of agency subpoenas in formal proceedings. ${ }^{23}$ The ABA and the Conference submitted a joint legislative package to Congress consisting of these four items and the sovereign immunity amendment. The Senate and the House held hearings on the

17 Id.

18 Report of the Special Comm. on Revision of the Administrative Procedure Act, 95 A.B.A. Rep. 322 (1970).

19 Infra notes 22-25. See Administrative Conference Report on ABA Proposals to Amend the Administrative Procedure Act (May 24, 1973), 3 A.C.U.S. 567 (1974); Statement of the Administrative Conference on the ABA Proposal to Amend the Administrative Procedure Act, 3 A.C.U.S. 53 (1974); 38 Fed. Reg. 16,841 (1973), amended by 39 Fed. Reg. 23,041 (1974).

${ }^{20}$ Statement of the Administrative Conference on the ABA Proposal to Amend the Administrative Procedure Act, 3 A.C.U.S. 53, 567-73 (1974).

21 Id. at 53-54, 573-75. This was based on the earher Conference recommendation 69-8, 1 C.F.R. $\$ 305.69-8$ (1985).

22 Id. at 55, 584-85. This was based on the earlier Conference recommendation 68-6, 1 C.F.R. \$305.68-6 (1985).

${ }^{23}$ Id. at 56-57, 594-98. The Conference reaffirmed tbis position in Recommendation 74-1, 1 C.F.R. $\$ 305.74-1$ (1985). 
proposals but ultimately only the sovereign immunity amendment was passed. ${ }^{24}$

In the late 1970's and early 1980's, reformers made a new effort to revise the APA through omnibus regulatory reform legislation. A six volume Study of Federal Regulation completed by the Senate Committee on Governmental Affairs in 1978 provided the foundation for these reform efforts. ${ }^{25}$ The $95 \mathrm{th},{ }^{26}$ 96th, ${ }^{27}$ 97th, ${ }^{28}$ and 98th ${ }^{29}$ Congresses all considered omnibus bills, but as the political composition of Congress changed, so did the content of these packages. The bills in the 95th and 96th Congresses emphasized simple procedures, ${ }^{30}$ agency flexibility in selecting administrative law judges (ALJs), and periodic review of ALJ qualifications. ${ }^{31}$ The later bills shifted the focus of reform efforts to rulemaking. ${ }^{32}$ The proposed reforms included requirements for hybrid rulemaking procedure ${ }^{33}$ and cost-benefit analyses, ${ }^{34}$ as well as tighter legislative and judicial review of agency rulemaking. ${ }^{35}$ In the 97 th Con-

24 See Administrative Procedure Act Amendments of 1976: Hearings before the Subcomm. on Administrative Practice and Procedure of the Senate Comm. on the Judiciary, 94th Cong., 2d Sess. (1976); Administrative Procedure: Hearings before the Subcomm. on Administrative Law and Governmental Relations of the House Comm. on the Judiciary, 94th Cong., 1st Sess. (1975). These hearings also considered separate bills embodying ABA proposals that did not receive support from the Conference.

${ }^{25}$ Staff of Senate Comm. on Governmental Affairs, 95th Cong., Study on Federal Regulation, Vols. 1-6 (Comm. Print 1977-78).

${ }^{28}$ S. 2490, 95th Cong., 2d Sess. (1978). See 124 Cong. Rec. S. 2194 (1978)(Statement of Sen. Ribicoff on introduction of S. 2490).

${ }^{27}$ S. 755, 96th Cong., 1st Sess. (1979)(Senate Comm. on Governmental Affairs version); H.R. 3263, 96th Cong., 1st Sess. (1979)(identical to S. 755); S. 2147, 96th Cong., 1st Sess. (1979)(Senate Comm. on the Judiciary version); S. 262, 96th Cong., 1st Sess. (1979).

${ }^{28}$ S. 1080, 97th Cong., 1st Sess. (1981). See Regulatory Reform Legislation of 1981: Hearings before the Senate Comm. on Governmental Affairs, 97th Cong., 1st Sess. (1981) [hereinafter cited as Regulatory Reform Legislation of 1981].

${ }^{29}$ S. 1080, 98th Cong., 1st Sess., (1983). See Regulatory Reform Act: Hearings before the Subcomm. on Administrative Practice and Procedure of the Senate Comm. on the Judiciary, 98th Cong., 1st Sess. (1983) [hereinafter cited as Regulatory Reform Act].

${ }^{30} \mathrm{~S}$. 2490 , supra note 26 ; S. 262 , supra note 27 .

${ }^{31}$ H.R. 3263, supra note 27 ; S. 262, supra note 27.

${ }^{32}$ S. 1080 , supra note 29 ; S. 755 , supra note 27 ; S. 262 , supra note 27 . See also Regulatory Reform Act, supra note 29.

${ }^{33}$ Id. See generally 124 Cong. Rec. S. 2194, supra note 25; Regulatory Reform Legislation: Hearings before the Senate Comm. on Governmental Affairs, 96th Cong., 1st Sess. (1979) [hereinafter cited as Regulatory Reform Legislation]; Regulatory Reform Legislation of 1981, supra note 28.

${ }^{34}$ Regulatory Reform Legislation of 1981, supra note 28.

${ }^{35}$ See, e.g., S. 1080, supra note 29 ; see also infra note 93 . 
gress, reform legislation passed unanimously by the Senate died in the House. This legislation was reintroduced in the 98th Congress, but by then Congress had lost interest. ${ }^{36}$

The drive for omnibus reform legislation lost momentum in part because of philosophical differences that emerged between the House and Senate over such issues as cost-benefit analysis and the role of the Office of Management and Budget (OMB) in rulemaking. In addition, the Reagan Administration, originally supportive of the legislation, grew less comfortable with some of its provisions and more willing to pursue its deregulatory goals through authority arrogated to the executive branch through the OMB regulatory review process. ${ }^{37}$

Despite its failure to amend the APA, Congress has adopted many significant changes in the area of administrative law. Recent statutes dealing with agency procedure on a government-wide basis include the Government in the Sunshine Act, ${ }^{38}$ the Equal Access to Justice Act, ${ }^{39}$ the Federal Advisory Committee Act, ${ }^{40}$ the National Environmental Policy Act, ${ }^{41}$ the Privacy Act of $1974,{ }^{42}$ and the Regulatory Flexibility Act. ${ }^{43}$ Furthermore, individual substantive statutes enacted in recent years have frequently contained their own, sometimes unique, provisions. A 1972 report to the Administrative Conference, surveying regulatory statutes that required procedures in addition to notice and comment for the adoption of

\footnotetext{
${ }^{38}$ See generally Regulatory Reform Act, supra note 29; Regulatory Reform Legislation of 1981, supra note 28; Regulatory Reform Legislation, supra note 33; 124 Cong. Rec. S. 2194, supra note 26.

${ }^{37}$ See Exec. Order No. 12,498, 50 Fed. Reg. 1036 (1985); Staff of Senate Committee on Governmental Affairs, 99th Cong., 2d Sess., Rep. No. 99-134 (1986); Bagby, Regulatory Impact Analysis: Toward Reasonable Economic Impact from Federal Regulations, 19 New Eng. L. Rev. 533 (1984). On February 10, 1986, the ABA Committee on Administrative Law recommendation supporting executive oversight of federal agency rulemaking was passed by the ABA House of Delegates. ABA Committee on Administrative Law, Executive Oversight (Draft report 1986). See Olsen, The Quiet Shift in Power: Office of Management and Budget Suspension of Environmental Protection Agency Rulemaking under Executive Order 12,291, 4 Va. J. Nat. Resources L. 5 (1984) (describing critically OMB review process). See also Strauss, The Place of Agencies in Government Separation of Powers and the Fourth Branch, 84 Colum. L. Rev. 573 (1984).

${ }^{38} 5$ U.S.C. § $552 b$ (1982 \& Supp. 1984).

${ }^{30} 5$ U.S.C. § 504, 28 U.S.C. § 2412 (1982 \& Supp.1984).

105 U.S.C. app. 2 1 (1982 \& Supp. 1984).

1142 U.S.C. $\S \S 4321-47$ (1982 \& Supp. 1984).

125 U.S.C. § 552a (1982 \& Supp. 1984).

435 U.S.C. $\$ \S 601-12$ (1982).
} 
rules of general applicability, concluded that the procedural provisions in these statutes were "almost unbelievably chaotic" and that these provisions responded to pressures for additional procedural rights in a "totally ad hoc fashion." 44 This trend, which shows no sign of abating, has contributed to what former Chairman of the Conference Antonin Scalia referred to as the "balkanization" of administrative procedure. ${ }^{45}$ One court, dismayed by the variety of statutory provisions, complained, that "[o]ne would almost think there had been a conscious effort never to use the same phraseology twice."46

The Administrative Procedure Act no longer dominates the field of federal administrative law as it did in 1946. Indeed, most of today's battles in administrative law are fought on different terrain. The diminished centrality of the APA presents a challenge to today's scholars and reformers of administrative procedure to restore the APA to its former place as the charter of administrative procedure, or at least the preferred model absent compelling grounds for deviation.

A focus on APA reform is not premised on blind preference for tradition, but on a belief in the value of uniformity in administrative law and procedure. Indeed, the principle that administrative procedures should be uniform was the bedrock of the APA. Judge Antonin Scalia lucidly set forth the values served by adherence to this principle in a 1974 letter to Congressman John Dingell commenting on the provisions of the Magnuson-Moss Warranty-Federal Trade Commission Improvement Act: ${ }^{47}$

In recent years, there has been a visible and steady erosion of standardized administrative practice, through individualized provisions contained in new pieces of regulatory legislation where no real reason for individualized treatment exists. While absolute standardization, of course, is not desirable, the basic principle of a uniform administrative practice, with only such variations as operational differences justify, serves several important values. It is indispensible to the retention of an administrative system that can be

\footnotetext{
4 Hamilton, Procedures for the Adoption of Rules of General Applicability: The Need for Procedural Innovation in Administrative Rulemaking, 60 Calif. L. Rev. 1276, 1315 (1972).

45 1972-73 Report, Admin. Conf. of the U.S. 2.

tB Associated Indus. of New York State v. U.S. Dep't of Labor, 487 F.2d 342, 345 (2d.Cir. 1973).

4715 U.S.C. $\$ \S 2301-12$ (1982).
} 
fathomed by the general public and penetrated by lawyers who are not specialists in narrow fields of Federal practice. It is helpful to the courts in their review of agency action, facilitating the development of overall principles of judicial review and enabling the creation of a body of case law that can serve as precedent in more than one limited field. Finally, and perhaps most important, an allegiance to a standard body of procedural principles such as that contained within the APA has great advantages in the legislative process. The procedural provisions of major substantive legislation are understandably not the portions to which the Congress devotes its closest attention; and the comments it receives from both the agencies and the private sector are inclined to dwell upon the extent, rather than the manner, of the regulation that is to be imposed. It is generally desirable, then, for the Congress to adhere to the judgements it made when procedure itself was the center of its attention rather than merely the incidental accompaniment of a substantive program under examination. Those judgements are likely to be significantly more sound than the random procedural innovations which may slip by with each new piece of substantive legislation. ${ }^{48}$

Legislators must resist the tendency to adopt ad hoc solutions of administrative procedural problems. ${ }^{49}$ A continuing theme of Administrative Conference recommendations, therefore, has been that Congress should be chary of legislating individual procedural requirements in individual substantive statutes over and above those in the APA. In Recommendation 72-5, for example, the Conference stated that statutory requirements beyond those set forth in section 553 "should not be imposed in the absence of special reasons for doing so, because the propriety of additional procedures is usually best determined by the agency in light of the needs of particular rulemaking proceedings." Ro Recommendation 83-3 urged that Congress avoid creating procedures for internal review of decisions

${ }^{18}$ Letter from Antonin Scalia, Chairman of the Administrative Conference of the United States, to Congressman John Dingell (May 23, 1974).

40 The Magnuson-Moss Act offers a good example of the problems to which Judge Scalia referred. An Administrative Conference study of Federal Trade Commission experience with the rulemaking provisions of the Act concluded that the hybrid procedures had not achieved the congressional goal of controlling agency discretion. The study also concluded that the Act's novel procedural requirements imposed high transition costs on the agency which was not permitted sufficient lead time to develop internal structures to implement new procedures. Recommendation 80-1, 1 C.F.R. $\S 305.80-1$ (1985).

so Recommendation 72-5, 1 C.F.R. $\S 305.72-5$ (1985). 
within agencies but recommended that Congress allow agency directors sufficient flexibility to devise review procedures suitable to the needs of the agency. ${ }^{51}$ The principle of Congressional adherence to the uniform requirements of the APA does not demand blind obedience; however, legislators must continually reexamine and, where necessary, revise the APA to reflect the accumulated experience of administrative law and to express a formula acceptable to the principal affected interests. The APA originally resulted from a carefully crafted compromise setting forth "a formula upon which opposing social and political forces [had] come to rest." changed their perceptions and expectations regarding the administrative process. The relative strengths of these interests have also fluctuated. Even the cast of characters has changed. The APA must address this reality or it will become increasingly less relevant to the practice of administrative law.

\section{REThinkING ThE APA}

The Administrative Conference and other concerned commentators must focus on rethinking the APA. This article suggests five particular areas for reexamination. ${ }^{53}$ I do not argue for particular

s1 Recommendation 83-3, 1 C.F.R. § 305.83-3 (1985).

s2 Wong Yang Sung v. McGrath, 339 U.S. 33, 40 (1950).

53 These five areas do not include, of course, controversies in the field of administrative law that lie outside the context of a discussion of revision of the APA. They also do not touch upon the subject of open government as embodied in the Freedom of Information Act, the Federal Advisory Committee Act, the Privacy Act of 1974, and the Government in the Sunshine Act. A widely shared perception exists that these statutes may have gone too far by protecting the public's right to know in preference to maintaining an agency climate conducive to careful dehiberation and a candid exchange of views. Recommendation 83-4, 1 C.F.R. § 305.83-41 (1984); Welborn, Lyons, \& Thomas, Implementation and Effects of the Federal Government in the Sunshine Act, 1984 A.C.U.S. 197, 199. These statutes, while located within or alongside the APA, are a separato area for discussion.

These five areas of discussion also do not include the current disputes over the allocation of congressional and executive authority and responsibilities in agency rulemaking. The Supreme Court's decision in INS v. Chadba, 462 U.S. 919 (1983), did not put to rest the question of the legislative veto. Admin. Conf. of the U.S., Legislative Veto of Agency Rules after I.N.S. v. Chadha (1984); Kaiser, Congressional Control of Executive Actions in the Aftermath of the Chadha Decision, 36 Ad. L. Rev. 239 (1984); Note, The Aftermath of Chadha: The Impact of the Severability Doctrine on the Management of Intragovernmental Relations, 71 Va. L. Rev. 1211 (1985). Congress may still devise a procedure that will pass constitutional muster.

Meanwhile, the role of the Office of Management and Budget in coordinating the 
statutory changes. The plain fact is that the development of both case law and legal culture has eroded the consensus which undergirded many portions of the 1946 Act. Where reexamination does not lead to revision of the APA, it may still renew our confidence in the existing provisions of the Act.

\section{A. Rulemaking}

The APA requires that agency decisionmaking be conducted either by formal "on the record" hearings or by a notice and comment process. This dichotomy is no longer as acceptable to the courts, to the Congress, or to the public as a basis for administrative action, at least for those regulatory actions that have a significant effect on private interests. Formal rulemaking, whatever its conceptual virtue in ensuring due process, has failed in practice because it emphasizes trial-type procedures that are not suited for exploration of the general characteristics of an industry. A wise judge observed that "rational decision is not furthered by requiring the agency to lose itself in an excursion into detail that too often obscures fundamental issues rather than clarifies them." "54

On the other hand, the notice-and-comment alternative was not conceived as an adversary process with full party participation. It was designed to provide alternative means for an agency to supplement information in its possession and to expose its preliminary conclusions to a range of public perspectives. However laudable, this process does not permit the interested public to directly address the information on which the agency proposes to rely, nor does it require the agency to explain in detail the reasoning behind its conclusions. Both procedures, therefore, fail to meet expectations of rational decisionmaking and public accountability, particularly in an era of deep suspicion of government. The omnibus regulatory reform legislation sought an acceptable formula for so-called hybrid rulemaking-informal rulemaking procedures that include some features of formal proceedings for resolution of factual issues.

rulemaking activities of Executive Branch agencies under Executive Order No. 12,291, 3 C.F.R. 12291 (1982), and Executive Order No. 12,498, 50 Fed. Reg. 1036 (1985), has provoked lively controversy. See supra note 37 . Power relationships among the branches of government affect administrative procedure, but they also reflect the rising or falling political fortunes of the branches rather than a broad consensus as to what is good procedure.

s4 WBEN, Inc. v. United States, 396 F.2d 601, 618 (2d Cir. 1968) (Friendly, J.), cert. denied, 393 U.S. 914 (1968). 
Although no government-wide legislation emerged from these efforts, much informal rulemaking has been transformed into a hybrid set of decisionmaking procedures by statutory requirements, Executive Orders, Conference recommendations, ${ }^{55}$ and most of all, by expanded judicial review. The Supreme Court in Vermont Yankee Nuclear Power Corp. v. NRDC,,6 however, restricted such aggressive judicial review by converting the procedural minima of the APA into a form of procedural maxima. The court arrested the growing trend among reviewing courts of remanding agency rules for additional procedural steps beyond those prescribed by the APA. Some commentators have criticized the decision as sweeping away "surefooted, painstaking, and cautious opinions of the courts of appeals," activism. ${ }^{58}$ Nevertheless, the decision has significantly influenced the lower courts, ${ }^{59}$ and it has focused attention on the ability of section 553 to meet the demands of modern regulatory rulemaking.

The disparity between section 553 and current administrative practice, however, suggests that any comprehensive revision of the APA should synthesize the many legislative proposals for revision of that section of the Act. At the same time, a revised section 553 may do more harm than good. The APA prescribes minimum procedural standards, and the familiar notice and comment process

ss See Magnuson-Moss Warranty-Federal Trade Commission Improvement Act, 15 U.S.C. \$ 2301-12 (1982); Recommendation 79-1, 1 C.F.R. § 305.79-1 (1985). While the Conference, in Recommendation 72-5, 1 C.F.R. $\$ 305.72-5$ (1985), urged Congress to eschew statutory rulemaking procedures beyond those called for in $\$ 553$, it recognized that agencies would often benefit by voluntarily utilizing additional procedures. See Recommendation 76-3, 1 C.F.R. § 305.76-3.

Bs 435 U.S. 519 (1978).

${ }^{87}$ See, e.g., $1 \mathrm{~K}$. Davis, Administrative Law Treatise $\$ 6.37$ (2d. ed. 1978); Davis, Administrative Common Law and the Vermont Yankee Opinion, 1980 Utah L. Rev. 3, 17. Professor Stewart has suggested that "Vermont Yankee is myopic in denying courts an adequate role in adjusting and updating the law." Stewart, Vermont Yankee and the Evolution of Administrative Procedure, 91 Harv. L. Rev. 1805, 1820 (1978). See also Byse, Vermont Yankee and the Evolution of Administrative Procedure: A Somewhat Different View, 91 Harv. L. Rev. 1823 (1978).

ss See, e.g., Scalia, Vermont Yankee: The APA, the D.C. Circuit and the Supreme Court, 1978 Sup. Ct. Rev. 345. While Judge Scalia approved of the decision, he also felt that it signaled the need for a major revision of the APA's rulemaking provisions. Id. at 375-409.

s9 The reaction of the lower federal judiciary to Vermont Yankee is painstakingly detailed in Neely, Vermont Yankee Nuclear Power Corporation v. Natural Resources Defense Counsel, Inc.: Response and Reaction in the Federal Judiciary, 14 U. Balt. L. Rev. 256 (1985). 
probably suffices for many, if not most, rulemaking decisions. Unless Congress can devise an effective statutory threshold that distinguishes the rules that require only the notice and comment process from those that demand more elaborate procedures, statutory revision may only hamper the efficiency and quality of administrative decisionmaking.

Efforts to reform the APA should also consider expanding the scope of existing notice and comment requirements. The Administrative Conference has recommended that exemptions from the requirements for notice and comment, particularly those in section 553 for military, foreign affairs, and proprietary functions should be eliminated or narrowed..$^{60}$ Similarly, the Conference has long urged that despite the exemption for interpretative rules, agencies should generally follow notice and comment procedures to ensure an effective decisionmaking process and public accountability. ${ }^{61}$ Moreover, where public participation is omitted prior to adoption of a rule because of time constraints, the agency should allow a meaningful opportunity for post-adoption comment by interested parties. $^{62}$ These revisions may bolster the openness to public participation that is one of the essential features of the APA. As the District of Columbia Circuit recently pointed out, "[t]he APA establishes procedural requirements for rulemaking precisely because they are presumed to elicit responses which, when given the requisite consideration by the agency, may affect its decision."

\section{B. Structures for Formal Administrative Adjudication}

Although questions of agency decisionmaking structure are of less immediate concern than purely procedural issues to participants seeking to navigate the administrative process, questions of structure bear heavily on the efficiency and credibility of the administrative process. This is particularly true of the process of making determinations "on the record after opportunity for an agency hearing."

- See supra note 21.

-1 Recommendation 76-5, 1 C.F.R. $\$ 305.76-5$ (1985).

${ }^{2}$ Id.

63 Simmons v. Interstate Commerce Commision, 757 F.2d 296, 300 (D.C. Cir. 1985).

o4 5 U.S.C. $\S 554$ (a) (1982). 
sionmaking structure includes a number of interesting questions. ${ }^{65}$ First and foremost is whether the role and status of the administrative law judge should be redefined.

ALJs preside over and are the initial fact finders in almost all formal administrative adjudications, ${ }^{66}$ and are therefore the decisionmakers in the vast bulk of "trials" in the federal system. Although ALJs are agency employees, they may not be disciplined or removed except for good cause as determined by the Merit System Protection Board after opportunity for a hearing. Thus, in most respects, ALJs are independent of the agency that employs them. ${ }^{67}$ This insulation from agency control or coercion assures impartiality at the trial stage in formal proceedings, a vital feature of the APA. ${ }^{68}$

ALJ independence also has a cost, because it may inhibit the development of a meaningful system for holding ALJs accountable by rewarding good performance or correcting poor performance. The Carter administration fired the opening shot in the current battle over ALJ independence in 1979 by proposing as part of its omnibus regulatory reform package that ALJs be appointed for a term of years renewable on the basis of a performance evaluation. ${ }^{69}$ Congress rejected this proposal and refused to consider it in subsequent omnibus reform bills. The issue of ALJ accountability has attained additional visibility recently because of disputes between the Social Security Administration and its ALJs over the handling

${ }^{85}$ See Lubbers, Federal Agency Adjudications: Trying to See the Forest for the Trees, 31 Fed. B. News \& J. 383 (1984), for background on many of the issues discussed in the following paragraphs.

${ }_{68}$ The number and importance of federal hearing officers who are not ALJs has also grown substantially in recent years, giving rise to issues concerning their role and independence. See Id. at 386-87.

${ }^{87}$ See 5 U.S.C. $\$ \S 1305,3105,3344,5372,7521$ (1982 \& Supp. 1984)(successors to section 11 of original APA).

68 The independence of Social Security ALJs in the face of pressures to increase production and to decrease agency allowance rates has been a subject of controversy for years. See Staff of the Subcomm. on Oversight of Government Management of the Senate Comm. on Governmental Affairs, The Role of the Administrative Law Judge in the Title II Social Security Disability Program, 98th Cong., 1st Sess. (Comm. Print 1983); Staff of Subcomm. on Social Security of the House Comm. on Ways and Means, Social Security Administrative Law Judges: Survey and Issue Paper, 96th Cong., 1st Sess. (Comm. print 1979).

${ }^{60}$ See Regulatory Reform Legislation: Hearings before the Senate Comm. on Governinental Affairs, 96th Cong., 1st Sess. 245 (1980)(Statement of John P. White, Deputy Director of the Office of Management and Budget). The two leading bills on this subject were S. 262 and $S .755$, supra note 27 . 
of disability cases. ${ }^{70}$ The Merit System Protection Board has upheld, within limits, the Social Security Administration's right to impose quantitative output performance standards, but the courts have criticized the Administration's recent efforts to decrease the number of decisions favorable to claimants. ${ }^{71}$

Administrative reformers may wish to consider other proposals to enhance ALJ performance and accountability, including a peer review system, as proposed by Professor Victor Rosenblum, ${ }^{72}$ or a promotion ladder within the ALJ system, as proposed by Judge Scalia. ${ }^{73}$ Another proposal that has also attempted to accommodate the goals of independence and accountability advocates removing ALJs from the agencies and organizing them in a central corps. ${ }^{74}$ For Congress to establish a corps, legislation must address subsidiary questions regarding how the corps should be organized and what authority it should have over adjudicative procedures. ${ }^{75}$

The debate over the status of ALJs also raises the issue of whether ALJ decisions should be accorded greater finality. The APA provides that when reviewing initial decisions of ALJs, the agency head has all of the powers it would have had in making the initial decision itself. ${ }^{76}$ The only qualification is that the ALJ decision becomes part of the administrative record and thus may be used to persuade the reviewing court that the agency decision is arbitrary or not supported by substantial evidence. ${ }^{77}$ The ABAsponsored amendments of the 1960's proposed increasing the weight given to ALJ decisions. A number of recent statutes have

${ }^{70}$ SSA v. Goodman, No. HQ 75218210015 (MSPB Feb. 6, 1984). See generally Rosenblum, Contexts and Contents of "For Good Cause" as Criterion for Removal of Administrative Law Judges: Legal and Policy Factors, 6 W. New Eng. L. Rev. 593 (1984) (concluding that the "good cause" standard for removal of administrative law judges is less demanding than the constitutional "good hehavior" standard but stronger than "efficiency of service").

${ }^{71}$ See Barry v. Heckler, 620 F. Supp. 779, 783 (N.D.Cal. 1985); Association of Administrative Law Judges, Inc. v. Heckler, 594 F. Supp. 1132, 1142 (D.D.C. 1984).

72 Rosenblum, Evaluation of Administrative Law Judges: Aspects of Purpose, Pohicy and Feasibility (unpublished report to the Administrative Conference 1981).

${ }_{73}$ Scalia, The ALJ Fiasco-A Reprise, 47 U. Chi. L. Rev. 57, 75-80 (1979).

74 See the proposed Administrative Law Judge Corps Act, S. 673, 99th Cong., 1st Sess. (1985); S. 1275, 98th Cong., 1st Sess. (1983).

${ }^{73}$ For a thorough airing of this debate, see The Central Panel System: A New Framework for the Use of Administrative Law Judges, 65 Judicature 233-76 (November 1981); $6 \mathrm{~W}$. New Eng. L. Rev. 587-828 (1984)(symposium).

78 See, e.g., 5 U.S.C § 557(6) (1982).

77 Universal Camera Corp. v. NLRB, 340 U.S. 474, 493 (1951). 
departed from the APA by requiring that agency review of the ALJ decision be subject to the substantial evidence standard. ${ }^{78}$ Furthermore, a number of legislative proposals would prohibit administrative review of ALJ decisions in programs where Congress is particularly reluctant to confide adjudicating authority to the agency. ${ }^{79}$

The status of the ALJs and ALJ decisions is part of a larger problem as old as administrative law: how to combine investigating, litigating, and adjudicating functions in the same agency while assuring fairness to the parties. The APA's solution, internal separation of functions, has generally worked well, but it has always provoked uneasiness and dissatisfaction, especially among the private bar. ${ }^{80}$ Several regulatory schemes provide greater institutional separation. For example, in the National Labor Relations Board, the General Counsel, who, by statute, investigates and litigates charges, is independent of the Board that adjudicates the cases and makes general policy. ${ }^{81}$ The Occupational Safety and Health Act, enacted in 1970, vests rulemaking, investigation, and litigation authority in the Department of Labor and administrative adjudication in the independent Occupational Safety and Health Review Commission. ${ }^{82}$ In 1977, Congress followed the same model in the Federal Mine Safety and Health Act, ${ }^{83}$ which placed rulemaking and enforcement in a new bureau within the Department of Labor and adjudication in the independent Federal Mine Safety and Health Review Commission. ${ }^{84}$

${ }^{78}$ See 30 U.S.C. $\S \S 801,16(b)$ (1982).

${ }^{79}$ See S. 139, 99th Cong., 1st Sess. (1985). See also H.R. 3080, 99tb Cong., 1st Sess. (1985).

so See Asimow, Wben the Curtain Falls: Separation of Functions in the Federal Administrative Agencies, 81 Colum. L. Rev. 759 (1981).

s1 Labor Management Relations Act of 1947, 29 U.S.C. $\S \S 141,153$ (1982). The NLRB General Counsel serves a term of four years, and in practice at least, has been insulated from removal for the length of his term, 29 U.S.C. $\$ 153(d)$ (1982).

${ }_{82}$ Occupational Safety and Health Act of 1977, 5 U.S.C. $\$ \S 5108,5314,5315,7902 ; 15$ U.S.C. $\S \S 633,636 ; 18$ U.S.C. $\S 1114 ; 29$ U.S.C. $\$ \S 553,651-678 ; 42$ U.S.C. $\S 3142 ; 49$ U.S.C. App. § 1421 (1982).

${ }^{\mathbf{s}}$ Federal Mine Safety and Health Act of 1977,30 U.S.C. $\$ \S 801$ et. seq. (1982).

si The proposal for a central ALJ corps illustrates another type of institutional separation of functions. This proposal is a step towards establishment of an administrative court, even though, under the current proposals, final decisionmaking authority remains with the agency. As such, it is a significant departure from the APA model of separation of functions. 
The less rigid separation of functions principle of the APA is based on the desirability of concentrating expertise and responsibility for policymaking in a single decisionmaker, the agency head. In recent years, however, formal adjudication has taken a back seat to rulemaking as a means to formulate principles of general applicability. Thus, the relative significance of policymaking as a component of formal adjudication has markedly decreased. In addition, deregulation has reduced the caseload at several agencies that relied heavily on formal proceedings for granting licenses or regulating rates. ${ }^{85}$ Meanwhile, caseloads have soared at agencies that use formal adjudication to administer benefit and entitlement programs or to impose civil penalties on violators of administered statutes. ${ }^{86}$ Neither type of case normally involves a significant policy element, though these cases require close familiarity with the statutory scheme. Thus, the changing nature of the typical subject matter of administrative adjudication may necessitate rethinking the decisionmaking structure adopted in the APA.

\section{Scope of Judicial Review}

The authors of the APA viewed its judicial review provisions as "a general restatement of the principles of judicial review embodied in many statutes and judicial decisions." statute, these provisions retained the plasticity of judge-made law,

ss Some agencies have been eliminated completely. For example, tbe Civil Aeronautics Board was terminated by Congress in 1978. See 49 U.S.C. 1551 (1976 \& Supp.). See Cohen, Post-Sunset Administration of International Aviation Functions at DOT, in CAB Sunset Seminar: Future Administration of the International Aviation Functions of the CAB (U.S. Dept. of Transportation). The Reagan Administration has urged the abolition of the Interstate Commerce Commission. Budget of the United States Government 3-8 (Executive Office of the President, Office of Management and Budget).

Regulatory agency caseloads have decreased significantly in many agencies. However, since the two agencies that showed the largest increases, Health and Human Services (HHS) and the Department of Labor, are now also the largest administrative law court systems in the U.S., the actual total number of cases filed has doubled. Most of the remaining agencies' caseloads have remained stable or dropped considerably. It should be further noted that HHS cases comprise $90 \%$ of all administrative law cases filed. See Lubbers, Federal Agency Adjudications: Trying to See the Forest for the Trees, 31 Fed. B. News \& J. 383, 384 (1984).

8s See Diver, The Assessment and Mitigation of Civil Money Penalties by Federal Administrative Agencies, 79 Colum. L. Rev. 1436, 1443-45, 1478-85 (1979); Lubbers, A Unified Corps of ALJs: A Proposal to Test the Idea at the Federal Level, 65 Judicature 266, 268, 276 (1981). This trend conforms to Administrative Conference Recommendations 72-6, and 79-3 which call for agency imposition of civil money penalties after ALJ hearings. 1 C.F.R. $\S \S$ 305.72-6, 79-3 (1985).

${ }^{87} 5$ U.S.C. §§ 701-706 (1982). 
and as a result, it is not surprising that after forty years their accepted meaning differs from the 1946 understanding. Judicial decisions expanding such concepts as standing and ripeness have received widespread acceptance, in part because of the popular perception that prompt resolution of disputes is usually preferable to continued uncertainty.

Much of the current controversy over judicial review concerns the proper scope of review. ${ }^{88}$ The announced standards of review employed by the courts have changed little since 1946, but the materials that courts look at in applying these standards have changed dramatically. Until the early 1970's, the courts followed the black letter principle that in deciding whether a rule was arbitrary and capricious, a reviewing court assumed the existence of the state of facts cited by the agency as justifying the rule. ${ }^{80}$ The notion of reviewing a rule adopted in informal proceedings based on the administrative "record" was looked upon as something of a contradiction in terms. ${ }^{90}$ All this has changed. The courts now generally believe that the rulemaking record is the yardstick by which the arbitrariness or rationality of the agency's action is measured.91 Questions as to the contents of the record and to what extent it should reflect governmental communications still remain open, ${ }^{92}$ but the principle is now firmly established that the rationality of administrative action must be tested by considering the information actually before the agency and not simply the facts that might have been used.

Still another controversy has centered on the proper deference accorded to administrative agencies by the courts. One controversial proposal in later versions of the omnibus regulatory reform

\footnotetext{
${ }^{88}$ Id. § 706.
}

${ }^{88}$ See Superior Oil Co. v. Federal Power Comm'n, 322 F.2d 601, 619 (9th Cir. 1963); DeLong, Informal Rulemaking and the Integration of Law and Pohicy, 65 Va. L. Rev. 257, 276$77 \&$ n.111 (1979).

${ }^{90}$ See Verkuil, Judicial Review of Informal Rulemaking, 60 Va. L. Rev. 185, 203-05 (1974).

91 This view was not questioned hy the Supreme Court in Vermont Yankee Nuclear Power Corp. v. NRDC, 435 U.S. 519, 541-49 (1978).

${ }_{92}$ Sierra Club v. Costle, 657 F.2d. 298, 320-21, 322-25 (D.C. Cir. 1981). See Recommendation 80-6, 1 C.F.R. § 305.80-6 (1985); Verkuil, Jawboning Administrative Agencies: Ex Parte Contacts by the White House, 80 Colum. L. Rev. 943 (1980); 1980 Report, Admin. Conf. of the U.S. 513 (1982). 
bills was the Bumpers Amendment, ${ }^{93}$ which responded to what was perceived as undue judicial deference to agencies' statutory interpretations. The dispute itself was conceptual and indeed frustrating to grapple with because the judicial deference of which the amendment's drafters complained was not so much a discrete principle of judicial review as a shorthand term for a number of reasons the courts have given for favoring an agency's reading of its statute. The Administrative Conference twice took formal positions against passage of the amendment, on the ground that "an across-the-board judgment that judicial deference to agency expertise or to an agency's interpretation of its statutory mandate is never warranted would be unwise."94 The debate did stimulate, however, efforts to revise section 706 of the APA to more closely reflect the case law on judicial review of agency action. It remains difficult, perhaps impossible, to capture in statutory language the precise mixture of respect and skepticism with which courts should approach administrative determinations. The phrase "take a hard look" may say all that can be said in guiding the courts. ${ }^{95}$ Nevertheless, revision of section 706 deserves a prominent place on any agenda of potential APA reform. ${ }^{96}$

\section{Alternative Procedures for Dispute Resolution}

The recent trend toward formalization of informal proceedings-most notably in the evolution of hybrid rulemaking-has coincided, ironically, with a growing dissatisfaction with the costs imposed by these procedures. Adversarial procedures, in particular, can impose high transaction costs on both agencies and the participating public. They may also create adversary relationships rather than manage existing ones and thus make consensual resolution of disputes more difficult. In addition, requiring agencies to explore alternatives or to perform research and analysis imposes obvious burdens on both time and resources, whether or not such research generates offsetting benefits in the form of improved knowledge.

\footnotetext{
as See, e.g., S. 2408, 94th Cong., 1st Sess. (1975).

-4 Recommendations 79-6, 81-2, 1 C.F.R. § 305.79-6, 81-2 (1985).

${ }^{\circ}$ Greater Boston Television Corp. v. FCC, 444 F.2d 841, 850-52 (D.C. Cir. 1970), cert. denied, 403 U.S. 923 (1971).

's See generally Levin, Federal Scope-of-Review Standards: A Preliminary Restatement, 37 Ad. L. Rev. 95 (1985) (summarizing federal scope-of-review doctrine in the context of a hypothetical revision of $\$ 706$ ).
} 
Accordingly, administrative law has cast about for alternative mechanisms for dispute resolution. An obvious example is negotiated rulemaking, a procedure still in the experimental stage, by which an agency brings together representatives of significant affected interests and gives them an opportunity to negotiate a rule addressing the contested issues. ${ }^{97}$ Providing opportunities and incentives for the affected interests to resolve outstanding rulemaking issues through negotiations may result in an improved, more efficient, and less expensive process. Negotiated rulemaking may also produce better agency decisions, because participation in the negotiating process both makes the resultant rule more acceptable to the affected interests; and provides rulemakers with unique insights and relevant information..$^{88}$

Formal agency adjudication, as well as rulemaking, is ripe for exploration of alternatives. A few agencies have started to implement alternatives to APA formal hearings. ${ }^{99}$ The Commodity Futures Trading Commission has been developing innovative procedures that channel reparation cases into three separate decision modes. ALJs continue to hear reparation cases in which customers file claims against commodities professionals involving more than $\$ 10,000$. However, smaller cases are decided in a "paper proceeding" with a telephone hearing possible. The CFTC has also established a voluntary abbreviated procedure in which a Commission employee issues a prompt unappealable decision with no precedential value outside the instant case. ${ }^{100}$ The Administrative Conference has begun research in this area and hopes to broaden the impact of such alternative procedures.

In 1983, the Merit Systems Protection Board, which is charged with deciding most employee grievances against federal agencies, introduced an appeals arbitration procedure as an alternative to its formal appeals process. Under this expedited process, the parties waive certain rights including formal discovery, some restrictions on ex parte communications, the right to hearing transcripts, and

\footnotetext{
${ }^{87}$ Of course, the agency retains ultimate responsibility for fashioning the final rule.

${ }^{88}$ Recommendations 82-4, 85-5, 1 C.F.R. §§ 305.82-4, 85-5 (1985).

${ }^{90}$ See infra notes 100-107 and accompanying text. See also Barrett, The Double Track Approach, 30 Fed. B. News \& J. 436 (1983); Lubbers, Dispute Resolution in Federal Agencies, 188 N.I.J. Reports/SNI 9 (1984).

${ }^{100} 17$ C.F.R. $\S \S 12.100-12.106$ (1985)(voluntary decision proceeding); Id. at $\S \S 12.200$ 12.210 (claim not exceeding $\$ 10,000$ ); Id. at $\$ \S 12.300-12.315$ (claim more tban $\$ 10,000$ ).
} 
the right to petition the Commission for review of the initial decision. The MSPB hearing officer typically takes an active role in advancing these expedited cases, encouraging settlements and issuing an abbreviated decision within sixty days. ${ }^{101}$

The Department of Health and Human Services Grant Appeals Board has created a small claims process through which the Board provides a mediator to help resolve or clarify disputes between HHS program officers and grantees. Some Board personnel have received mediation training. The Board also takes a highly active role in managing cases to expedite their handling. ${ }^{102}$ Professor Richard Cappalli of Temple University, who is currently studying the Board's operation under a contract with the Administrative Conference, has speculated that the Board's innovative procedures may become a national model for court reform. ${ }^{103}$

Agencies have also initiated alternatives to formal dispute resolution mechanisms in government contracts and other areas. NASA successfully used a minitrial to settle a multimillion dollar case with one of its contractors. ${ }^{104}$ The EPA can use arbitration proceedings under its pesticide registration program to establish the compensation due an applicant for EPA approval when the data it submitted is used by another applicant. ${ }^{105}$ Several agencies have promoted private sector dispute resolution procedures as an alternative to formal agency proceedings or litigation. In recent years, the Federal Trade Commission has required establishment of private arbitration programs in several agency orders to handle consumer grievances. An FTC consent decree with General Motors, for example, establishes Better Business Bureau arbitration of certain kinds of consumer complaints. ${ }^{106}$ These innovations are, for the most part, still new, and the practical, legal, and policy issues they raise need further exploration.

${ }^{101} 5$ C.F.R. $\S 1201.200$ (1985)(appeals arbitration).

10245 C.F.R. § 16.12 (1985).

${ }^{103}$ Cappalli, Dispute Processing at the Grant Appeals Board, (draft report on file with the Administrative Conference.)

104 Johnson, Masri \& Oliver, Minitrial Successfully Resolves NASA-TRW Dispute, Legal Times, Sept. 6, 1982 at 13. See Breger, The Justice Conundrum, 28 Vill. L. Rev. 923, 952-5 (1983); Green, Marks \& Olson, Settling Large Case Litigation: An Alternative Approach, 11 Loyola L.A.L. Rev. 493, 501 (1978).

${ }^{105}$ Federal Insecticide, Fungicide and Rodenticide Act, 7 U.S.C. $\S 136(a)(c)(1)(D)(i i i)$ (1982); 40 C.F.R. $\$ 152.93$ (1985).

${ }^{106}$ In re General Moters Corp., No. 9145, slip op. (FTC Nov. 16, 1983). 
Forty years ago, the APA compromise had administrative law borrow much of its formal process from the judicial model. Administrative law should today be prepared to adopt innovative techniques being developed by the judicial system for streamlining dispute resolution and for encouraging settlements. Many such innovations need not necessarily call for statutory amendments to the APA because section 554(c) already recognizes the desirability of consensual resolution by requiring agencies to grant all parties the opportunity to submit and consider offers of settlement and provides a right to a hearing only "to the extent that the parties are unable so to determine a controversy by consent." ${ }^{\text {"107 }}$ Indeed, one of the twelve ABA resolutions adopted in 1970 recommended amending the APA to require agencies "to the extent practicable and useful to provide by rule for prehearing conferences to facilitate and expedite the determination of the facts and issues involved in the proceeding." 108 The ABA's legislative drafting committee concluded, however, that section 554(c) provided sufficient authority for agencies to make effective use of prehearing conferences. ${ }^{109}$ Nevertheless, given the urgency of implementing improved methods of dispute resolution, any agenda for APA revision should include an inquiry into possible changes to the Act which might facilitate use of dispute resolution alternatives.

\section{E. Procedures for Informal Agency Action}

Reflection on the future development of administrative law must not lose sight of the large number of agency actions that are not subject to the APA's formal adjudication and rulemaking requirements. The Attorney General's Committee on Administrative Procedure devoted a chapter of its report to such informal methods of adjudication; noting that because "[c]omparatively few cases flower into controversies in which the parties take conflicting positions of such moment to them that resort is necessary to the procedure of the courtroom, . . . informal procedures constitute the vast bulk of administrative adjudication and are truly the lifeblood of the administrative process."110

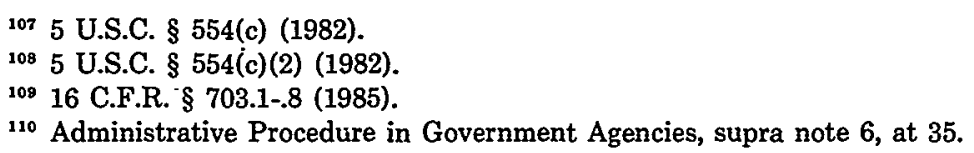


The drafters of the APA purposely eschewed any attempt to establish minimum procedural requirements for most "informal agency action." Nonetheless, without formalizing such decisionmaking, significant improvement is possible in the process by which these decisions are made. The Administrative Conference has had a continuing role in examining informal agency decisionmaking procedures and recommending structural improvements. In that regard, the Conference has consistently supported the general principle, set forth in Recommendation $71-3$, that agencies should enunciate and publicize their policy decisions where feasible. ${ }^{111}$ Since the Conference stated this general position in 1971, numerous program-specific recommendations have echoed this theme. ${ }^{112}$

A 1983 study of specific agency programs led the Conference to refine its position with respect to agency articulation of policy. In a statement adopted in June of 1983, the Conference-while affirming the general principle in Recommendation 71-3-set forth guidelines to help agencies identify those circumstances in which articulation of agency policy is desirable and practical. ${ }^{113}$ On the one hand, the Conference stated its belief that pohicy articulation provides

guidance to members of the public in planning their conduct, enables agency officials to control the quality and consistency of agency decisionmaking, reduces the costs of resolving disputes, provides persons threatened with adverse outcomes a more meaningful opportunity to participate in the decisionmaking process, facilitates judicial review of agency action, and facilitates political review of agency policy. ${ }^{114}$

On the other hand, the Conference recognized that the agency's choice whether or not to adopt a policy formulation depends on an

11 In Recommendation 71-3, 1 C.F.R. $\$ 305.71-3$ (1985), the Conference stated the general principle that :

[E]ach agency which takes actions affecting substantial public or private interests, whether after hearing or through informal action, should, as far as is feasible in the circumstances, state the standards that will guide its determination in various types of agency action, either through published decisions, general rules or policy statements other than rules. . . .

112 See Recommendations 71-4, 71-5, 75-1, 79-3, 1 C.F.R. $\S \S 305.71-4,71-5,75-1,79-3$ (1985); 2 K. Davis, Administrative Law Treatise $\S 8: 5-6$ (2d. ed. 1978).

1131 C.F.R. \& 310.9 (1985).

${ }^{114}$ Appendix to 1 C.F.R. $\S 310.9,48$ Fed. Reg. 31, 182 (1983). 
analysis of costs and benefits. Costs include the potential for noncompliance, overinclusive or underinclusive application of rules, rulemaking costs, and enforcement costs. ${ }^{115}$

Beyond the question of agency policy articulation, there are many other aspects of informal agency action - i.e., neither rulemaking nor adjudication governed by the APA - that warrant study and attention by those concerned with administrative procedure. We should consider whether problems exist, either of a generic or agency-specific nature, that should be addressed in future reform efforts.

\section{CoNCLUSION}

The APA has survived forty years, but it may perish as the charter of administrative procedure within another forty years-or even another fifteen-without more significant revision than it has received in the past. Legislative efforts at revision are increasing in frequency and intensity, and though for the time being they have failed, renewed efforts are certain to follow. Congress has "discovered" administrative procedure, a consequence of the realization that enacting a substantive program with sound goals and appropriating money for the program's administration does not in itself assure that programmatic goals will be achieved.

The initiative for "regulatory reform", which has dominated much of the discussion in administrative law over the past ten years, is derived from widely shared perceptions that many substantive programs are not working well and from budgetary realizations that give priority to pruning and improving existing programs rather than creating new ones. "Regulatory reform" has brought both procedural and substantive changes, but more remains to be done. The budgetary pressures imposed by the recently enacted Gramm-Rudman-Hollings Deficit Reduction Act ${ }^{116}$ will force both Congress and the Executive Branch to devote still more attention to achieving greater efficiency in existing programs. Improved administrative procedures will not necessarily provide solutions to what are in many instances extremely difficult choices

116 Pub. L. No. 99-177, 99 Stat. 1037 (1985). But see Synar v. U.S., 54 U.S.L.W. 2413, No. 85-3945 (D.C. Cir. 1986); appeal granted sub. nom. Bowsher v. Synar, U.S. Senate v. Synar, and O'Neill v. Synar, 54 U.S.L.W. 3548, Nos. 85-1377, 85-1378, and 85-1379 respectively. 
among competing values, but procedural solutions will nonetheless be sought (indeed, sometimes to avoid hard substantive choices). Those whose interest is administrative procedure must prepare to address such demands constructively, with such improvements as we can propose and with soundly based criticism of those proposals we cannot support. The Administrative Conference will be, as it has been in the past, a leader in this task. 
